\title{
The Relationship between Bioactive Compounds with Diastase Activity and Antibacterial Synergy of Honey and Potato Starch Combinations against Klebsiella pneumonia
}

\author{
Moussa Ahmed*, Baghdad Khiati, Saad Aissat Noureddine Djebli, Abdelmalek Meslem and Salima Bacha
}

Pharmacognosy and Api-Phytotherapy Research Laboratory, Mostaganem University, Algeria

\begin{abstract}
Honey samples produced by Apismellifera, both unifloral and multifloral from different sources in Algeria were examined for their antibacterial capacity and their synergism with potato starch. An agar incorporation technique was used to assess the minimum inhibition concentration (MIC) and the minimum inhibition additive concentration (MIAC) of honey against K. pneumoniae ATCC 27736. The physicochemical properties, a-amylases activity, total phenolic and flavonoid content, of six representative honey samples were determined. The MIC for the six varieties of honey without potato starch against $K$. pneumoniae ranged between $14 \%$ and $24 \%(v / v)$. When starch was incubated with honey and then added to media, an MIC drop was noticed with each variety and it ranged between $5.55 \%$ and $16.66 \%$. The total phenolic content of honey samples was between 1.50-108.21 mg GAE/100 g honey as gallic acid equivalent, total flavonoid content varied from 5.41 to $9.94 \mathrm{mg}$ Catechin/ $\mathrm{kg}$. Mean value for diastase was $16.55 \pm 2.8$ (range 7.3-23.5) expressed as diastase number in Gothe'sscale. No significant correlation was established between a-amylases activity and bioactive compounds. Honey: potato starch combinations show real potential for future use as a treatment for infections caused by K. pneumonia.
\end{abstract}

Keywords: Algerian honey; Antibacterial activity; Potato starch; Synergism; Bioactive compounds; Diastase activity

\section{Introduction}

Klebsiella pneumoniae, an important human pathogen, is the most common cause for pneumonia, bacteremia, and septicemia, is also involved in urinary tract infections (UTI) [1] Treatment of K. pneumoniae infections has become increasingly difficult because of the predominance of multiple-antibiotic-resistant strains [2,3]. Antibiotic resistance has increased substantially in recent years and is posing an ever-increasing therapeutic problem $[4,5]$. Honey is a natural, nontoxic, and inexpensive product for the need of novel therapies against bacterial infections. The clinical use of honey has an enormous potential, especially in the fight against antibiotic-resistant strains [5,6]. Several bioactive compounds have been identified in honey which contributed to its antibacterial action. The main factor is the high osmotic activity of honey, which does not allow bacterial growth [7]. Recent experimental finding indicated that the amylase present in honey increases the osmotic effect in the media by increasing the amount of sugars and consequently increasing the antibacterial activity [8]. Honey contains small amounts of different enzymes, notably, diastase ( $\alpha$-and $\beta$-amylase), invertase ( $\alpha$-glucosidase), glucose-oxidase, catalase and acid phosphatase, which come from nectar sources, salivary fluids and the pharyngeal gland secretions of the honeybee [9]. Diastase is a natural enzyme of honey. Alpha-amylase degrades starch to a mixture of the disaccharide maltose, the trisaccharide maltotriose and oligosaccharides known as dextrin's [10]. Also phenolic compounds may contribute to antimicrobial activity [11]. The inhibitory effects of polyphenols for $\alpha$-amylases have attracted great interest among researchers $[12,13]$. In this study, we evaluated the antibacterial activity of 6 varieties of honey against $K$. pneumoniae and their combination with potato starch in correlation with diastase number ( $\alpha$-amylase), and Bioactive Compounds (total flavonoid and polyphenol content).

\section{Materials and Methods}

\section{Honey samples}

Six $(n=6)$ commercial honeys of different floral sources and geographical origins where purchased from local market and left at room temperature until further analysis.

\section{Preparation of the stock starch solution}

The stock starch solution was prepared by dissolving $0.5 \mathrm{~g}$ of dried soluble starch in deionised water in a volumetric flask. After heating and stirring the solution for approximately ten minutes, starch was completely dissolved, and the volumetric flask was filled with deionised water to the mark.

\section{Bacterial culture and inoculum preparation}

Pure culture of K. pneumonia 27736 was obtained from the Department of Biology, Faculty of Sciences, Mostaganem University, Algeria. The bacteria was grown on Nutrient Agar (NA; Merck Germany) slant, incubated at $37^{\circ} \mathrm{C}$ for $24 \mathrm{~h}$, and kept at $4^{\circ} \mathrm{C}$ until further use. Bacterial suspension was prepared by inoculating one loopful of the 24-h-old bacterial colonies into $10.0 \mathrm{ml}$ of sterilized distilled water. The inoculums size was adjusted to match the turbidity of McFarland 0.5 scale $\left(1 \times 10^{8}\right.$ cells $\left./ \mathrm{ml}\right)$ and diluted with sterilized distilled water to the inoculums size of $1 \times 10^{7}$ cells $/ \mathrm{ml}$.

\section{Diastase activity (Diastase number)}

Diastase activity was measured with Phadebas, according to the Harmonized Methods of the European Commission of Honey [14].

*Corresponding author: Moussa Ahmed, Pharmacognosy and Api-Phytotherapy Research Laboratory, Mostaganem University, Algeria, Tel: +213 65234059; Fax: +213 65234059; E-mail: moussa7014@yahoo.fr

Received July 22, 2013; Accepted October 17, 2013; Published October 22, 2013

Citation: Ahmed M, Khiati B, Aissat S, Djebli N, Meslem A, et al. (2013) The Relationship between Bioactive Compounds with Diastase Activity and Antibacterial Synergy of Honey and Potato Starch Combinations against Klebsiella pneumonia. Clin Microbial 2: 131. doi: 10.4172/2327-5073.1000131

Copyright: @ 2013 Ahmed M, et al. This is an open-access article distributed under the terms of the Creative Commons Attribution License, which permits unrestricted use, distribution, and reproduction in any medium, provided the original author and source are credited. 
Citation: Ahmed M, Khiati B, Aissat S, Djebli N, Meslem A, et al. (2013) The Relationship between Bioactive Compounds with Diastase Activity and Antibacterial Synergy of Honey and Potato Starch Combinations against Klebsiella pneumonia. Clin Microbial 2: 131. doi: 10.4172/23275073.1000131

An insoluble blue dyed cross-linked type of starch is used as the substrate. This is hydrolysed by the enzyme, yielding blue water-soluble fragments, determined photometrically at $620 \mathrm{~nm}$. The absorbance of the solution is directly proportional to the diastatic activity of the sample. The diastase activity, expressed as $\mathrm{DN}$ or diastase number, was calculated from the absorbance measurements using Eqs. (1) and (2) for high (8-40 diastase units) and low (up to 8 diastase units) activity values, respectively:

$$
\begin{aligned}
& \mathrm{DN}=28.2 \times \Delta \mathrm{A} 620-2.64(1) \\
& \mathrm{DN}=35.2 \times \Delta \mathrm{A} 620-0.46(2)
\end{aligned}
$$

\section{Determination of Total Phenolic Content (TPC)}

The total phenolic content (TPC) was determined by the FolinCiocalteau method [15]. Thirty microliters $(\mu \mathrm{l})$ of honey solution $(0.1 \mathrm{~g} / \mathrm{ml})$ were mixed with $2.37 \mathrm{ml}$ of milli Q water and $150 \mu \mathrm{l}$ of $0.2 \mathrm{~N}$ Folin-Ciocalteu reagent. The solution was thoroughly mixed by vortexing and incubated for $2 \mathrm{~min}$ at room temperature. Four hundred and fifty microliters ( $\mu \mathrm{l}$ of sodium carbonate solution $(0.2 \mathrm{~g} /$ $\mathrm{ml}$ ) were added to the reaction mixture and further incubated for 2 $\mathrm{h}$ at ambient temperature. The absorbance was measured at $765 \mathrm{~nm}$ using a spectrophotometer. The total phenolic content was determined by comparing with a standard curve prepared using gallic acid $(0-200$ $\mathrm{mg} / \mathrm{l})$.The results were mean values \pm standard deviations and expressed as milligrams of gallic acid equivalents (mg GAE)/100 g of honey

\section{Determination of Total Flavonoid Content (TFC)}

The total flavonoid content (TFC) was assessed using aluminiumchloride assay [16]. A $10 \mu \mathrm{l}$ volume of a $10 \%(\mathrm{v} / \mathrm{v})$ honey solution was added to the wells of a 96 well plate; then $30 \mu \mathrm{l}$ of a $2.5 \%$ sodium nitrite, $20 \mu \mathrm{l}$ of $2.5 \%$ aluminium chloride solutions and then $100 \mu \mathrm{l}$ of a $2 \%$ sodium hydroxide solution were sequentially added. The samples were mixed well and Abs $450 \mathrm{~nm}$ was measured. Total flavonoid content was expressed as mg of $(+)$-catechin equivalents (CEQ) per kg of honey.

\section{Antibacterial activity of honey alone}

Increased concentrations (5\%-50\% vol/ $\mathrm{vol}$ ) were incorporated into media to test their efficiency against K. pneumoniae 27736. Each plate with final volume of honey and media of $5 \mathrm{ml}$ was inoculated and incubated at $37^{\circ} \mathrm{C}$ for $24 \mathrm{~h}$. The MICs was determined by finding the plates with the lowest concentration of honey on which the strain would not grow. All MIC values were expressed in \% (v/v).

\section{Antibacterial synergism of honey and potato starch toward K.pneumoniae}

To evaluate the effect of starch on the antibacterial action of honey, $1 \%$ starch solution was prepared using sterile water. Different volumes from the stock solution were added to arrange of honey concentrations lower than the MIC. The same volume of starch solution that has given inhibition with honey was added alone to media as control to check whether or not starch alone has an inhibition effect against $K$. pneumoniae. An equivalent volume of water was added to honey instead of starch solution to confirm that additive inhibition is not due to the dilution of honey. The final volume in each plate was $5 \mathrm{ml}$. Starch content in media ranged between $1 \%$ and $8 \%(\mathrm{w} / \mathrm{v})$. Honey and starch as well as honey and water were incubated for $24 \mathrm{~h}$ at $37^{\circ} \mathrm{C}$ before being incorporated into media. Plates were inoculated and incubated at $37^{\circ} \mathrm{C}$ for 24 bioassay was performed in duplicate and repeated twice.

\section{Statistical analysis}

Analyses are representative of 3 independent experiments, and the data are presented as means \pm standard deviations. Correlations were established using Pearson's correlation coefficient $(r)$ in bivariate linear correlations $(p<0.01)$. All statistical analyses were performed with the Statistica 7.0 software for Windows.

\section{Results and Discussion}

\section{Diastase activity (Diastase number)}

The major enzymes present in honey are invertase, glucose oxidase and diastase, a mixture of $\alpha$-amylase and $\beta$-amylase. The honey samples analyzed in the present work show a range of values, between 22.1 and 7.3 Schade units. One sample (H5) has been shown value below 8 Schade units (Figure 5). The explanation for the low content of diastatic activity found in this one sample could be accounted for an inadequate processing or storage conditions.

\section{Total Phenolic Content (TPC)}

The amount of total phenolic content estimated using the FolinCiocalteu reagent in the different samples ranged from 63.93 to 95.36 mg (mg GAE/100 g honey) (Figure 4). The total phenolic content of certain honey samples has been previously determined $[17,18]$. For example, Dong, Zheng and $\mathrm{Xu}$ [19] has been reported that total phenols of in Chinese honey were 9.41 to $102.1 \mathrm{mg} \mathrm{GAE} / 100 \mathrm{~g}$. The concentration and type of polyphenolic substances depend on the floral origin of honey and are major factors responsible for biological activities, including antimicrobial activities [20].

\section{Total Flavonoid Content (TFC)}

The TFC of honey samples ranged from 5.41 to $9.94 \mathrm{mg} \mathrm{CE} / 100 \mathrm{~g}$ (Figure 6) and these values are higher than that of 0.25-4.27 mg CE/100 $\mathrm{g}$ as reported for Brazilian honeys [21]. Flavonoid contents in Tualang honey samples studied by Khalil et al. [22] were 4.74-22.76 mg CE/100 $\mathrm{g}$ of honey.

\section{Antibacterial activity of honey alone and in combination with potato starch toward $K$. pneumoniae}

In the present study, it was assessed the in vitro antibacterial action of honey alone and in combination with potato starch against K. pneumoniae, determined by agar incorporation method. The determination of all the MICs and MIACs was performed in duplicate. All varieties of honey were effective against the tested strain. Without starch, the MICs of the six varieties ranged between $14 \%(\mathrm{v} / \mathrm{v})$ and $24 \%$ $(\mathrm{v} / \mathrm{v})$. When starch was incubated with honey and added to media, the MIACs of the six varieties ranged between $8 \%(\mathrm{w} / \mathrm{v})$ and $20 \%(\mathrm{w} / \mathrm{v})$ which represents an MIC drop between $65.55 \%$ and 50\% (Figures

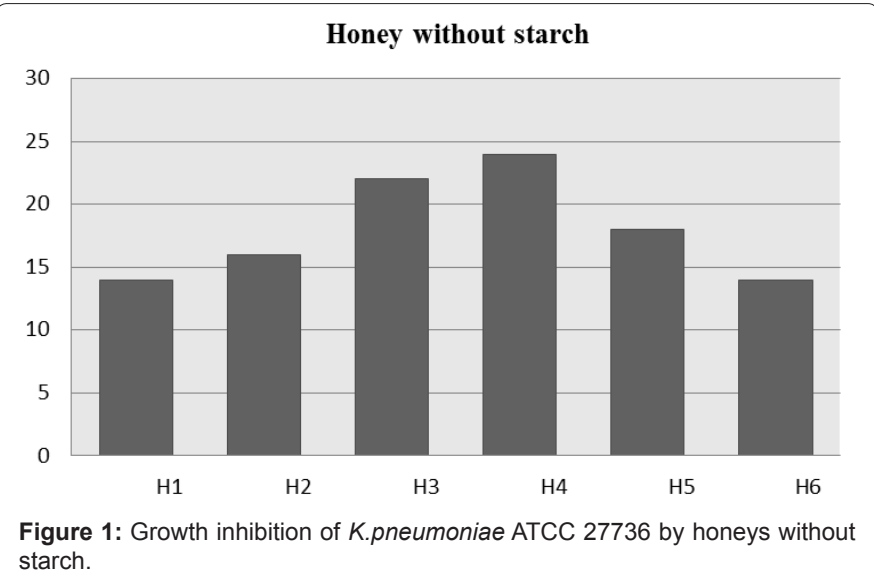

Figure 1: Growth inhibition of K.pneumoniae ATCC 27736 by honeys without starch. 
Citation: Ahmed M, Khiati B, Aissat S, Djebli N, Meslem A, et al. (2013) The Relationship between Bioactive Compounds with Diastase Activity and Antibacterial Synergy of Honey and Potato Starch Combinations against Klebsiella pneumonia. Clin Microbial 2: 131. doi: 10.4172/23275073.1000131

Page 3 of 4

1-3). The antimicrobial activity of honey against several pathogens and its dependence on the floral origin has been widely reported [23,24]. Several activities of honeys that contribute to their antibacterial effect are now well known. Osmolarity is an important factor in the efficacy of honey when used as an antibacterial agent for skin wounds [25]. A recent study by Ahmed et al. [26] has been demonstrated that osmosis determined the bactericidal effects of starch and honey towards Escherichia coli and Pseudomonas aeruginosa.The use of sugar for the treatment of infected wounds was investigated in vitro experiments with bacteria pathogenic to humans, such as E. coli, $P$. aeruginosa, S. aureus and K. pneumoniae [27]. Amylases present in honey were expected to split starch chains to randomly produce

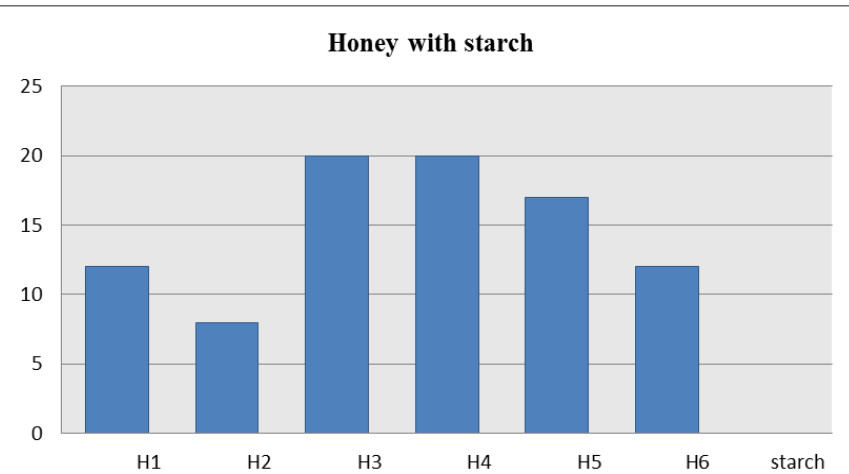

Figure 2: Growth inhibition of K.pneumoniae ATCC 27736 by honeys with starch.

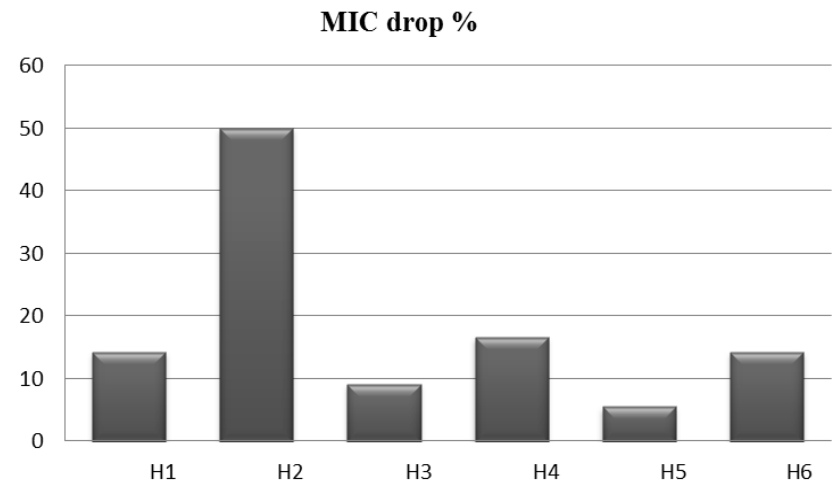

Figure 3: The percentage of the MIC drop \%

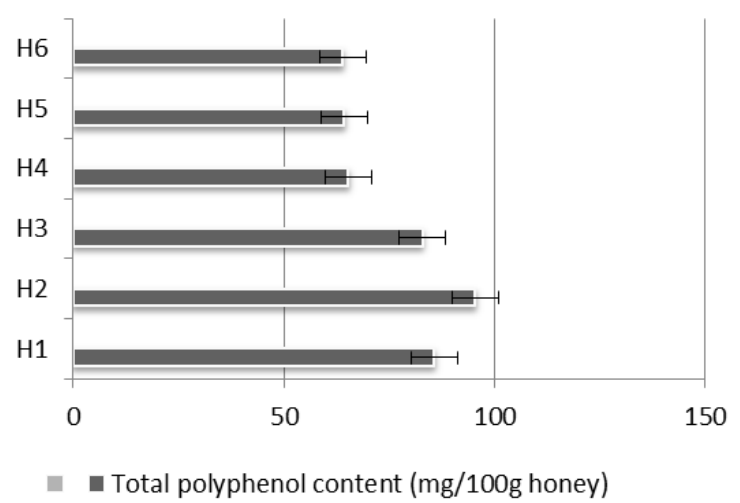

Figure 4: Total polyphenol content (mg GAE/kg) of honey samples.

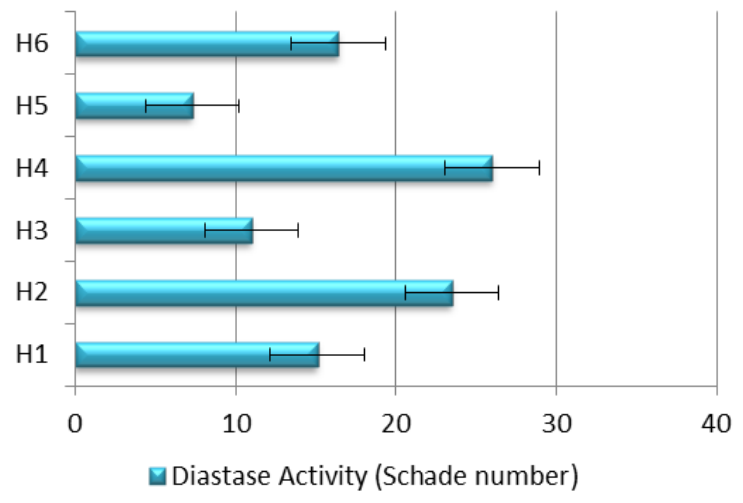

Figure 5: Diastase activity of honey samples.

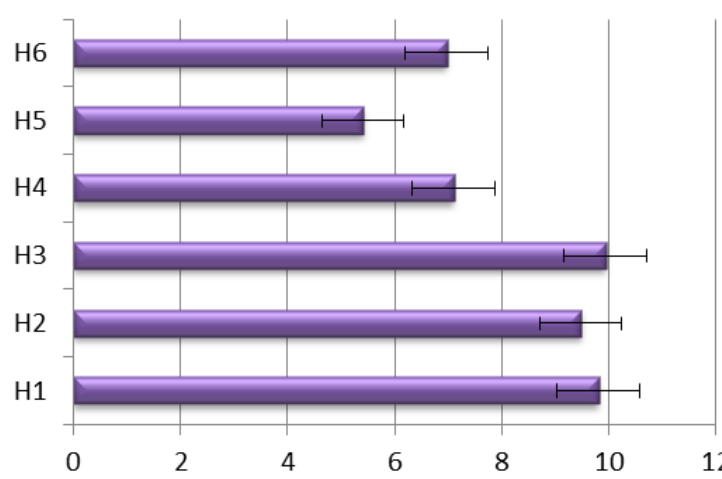

Total flavonoids content ( $\mathrm{mg} \mathrm{CE} / \mathrm{Kg}$ honey)

Figure 6: Total flavonoids content $(\mathrm{mg} \mathrm{CE} / \mathrm{kg}$ ) of honey samples.

dextrin and maltose and probably increase the osmotic effect in the media by increasing the amount of sugars and consequently increase the antibacterial activity [28]. The mechanism of honey antibacterial activity is complex and might be attributed to the synergistic activity between its various potent biological ingredients such as polyphenols and flavonoids [29,30]. Flavonoids are the most common polyphenols and are widely studied as $\alpha$-amylase inhibitors [31]. However, in the present study, No significant correlation was established between a-amylases activity and bioactive compounds.

\section{Conclusions}

In conclusion, the results of this preliminary study highlight synergy between honey and potato starch, when used against K. pneumoniae which could be harnessed to improve their antibacterial capacity.

\section{Acknowledgments}

Authors thank Staff of Mostaganem University for providing material

\section{Conflict of Interest}

We declare that we have no conflict of interest.

\section{References}

1. Oelschlaeger TA, Tall BD (1997) Invasion of cultured human epithelial cells by Klebsiella pneumoniae isolated from the urinary tract. Infect Immun 65: 2950 2958.

2. Arlet G, Rouveau M, Casin I, Bouvet P J, Lagrange P H, et al. (1994) Molecular epidemiology of Klebsiella pneumoniae strains that produce SHV-4-blactamase and which were isolated in 14 French hospitals. J Clin Microbiol 32 2553-2558. 
Citation: Ahmed M, Khiati B, Aissat S, Djebli N, Meslem A, et al. (2013) The Relationship between Bioactive Compounds with Diastase Activity and Antibacterial Synergy of Honey and Potato Starch Combinations against Klebsiella pneumonia. Clin Microbial 2: 131. doi: 10.4172/23275073.1000131

3. Meier C, Oelschlaeger TA, Merkert H, Korhonen TK, Hacker J (1996) Ability of Escherichia coli isolates that cause meningitis in newborns to invade epithelial and endothelial cells. Infect Immun 64: 2391-2399.

4. Austin DJ, Kristinsson KG, Anderson RM (1999) The relationship between the volume of antimicrobial consumption in human communities and the frequency of resistance. Proc Natl Acad Sci U S A 96: 1152-1156.

5. Mercan N, Guvensen A, Celik A, Katircioglu H (2007) Antimicrobial activity and pollen composition of honey samples collected from different provinces in Turkey. Nat Prod Res 21: 187-195.

6. Kwakman PH, Van den Akker JP, Güçlü A, Aslami H, Binnekade JM, et al. (2008) Medical-grade honey kills antibiotic-resistant bacteria in vitro and eradicates skin colonization. Clin Infect Dis 46: 1677-1682.

7. Ahmed M, Aissat S, Djebli N, Aboud B ,Meslem A et al. (2011) The Influence of Starch of Ginger on the Antibacterial Activity of Honey of Different Types from Algerian against Escherichia coli and Staphylococcus aureus. International Journal of Microbiological Research 3: 258-262.

8. Ahmed M, Djebli N, Aissat S, Douichene S (2012) The Relationship between fructose, glucose and maltose content with Diastase number and antiPseudomonal activity of natural honey combined with potato starch. Organic Chem Curr Res 1:6

9. Huidobro J F, Santana F J, Sanchez M P, Sancho M T, Muniategui S et al (1995) Diastase, invertase and a-glucosidase activities in fresh honey from north-west Spain. Journal Apiculture Research1995 34: 39-44.

10. SakaÄ N, Sak-Bosnar M (2012) A rapid method for the determination of honey diastase activity. Talanta 93: 135-138.

11. Estevinho L, Pereira AP, Moreira L, Dias LG, Pereira E (2008) Antioxidant and antimicrobial effects of phenolic compounds extracts of Northeast Portugal honey. Food Chem Toxicol 46: 3774-3779.

12. Kawakami K, Aketa S, Nakanami M, lizuka S, Hirayama M (2010) Major watersoluble polyphenols, proanthocyanidins, in leaves of persimmon (Diospyros kaki) and their alpha-amylase inhibitory activity. Biosci Biotechnol Biochem 74: 1380-1385.

13. McDougall GJ, Shpiro F, Dobson P, Smith P, Blake A, et al. (2005) Different polyphenolic components of soft fruits inhibit alpha-amylase and alphaglucosidase. J Agric Food Chem 53: 2760-2766.

14. Bodganov S, Martin P, Lüllmann C (1997) Harmonised methods of the European Honey Commission. Apidologie

15. Singleton V L, Orthofer R, Lamuela-Raventos R M (1999) Analysis of tota phenols and other oxidation substrates and antioxidants by means of FolinCiocalteu reagent. Methods in Enzymology 299: 265-275.

16. Amaral S, Mira L, Nogueira JMF, Pereira da silva A, Florencio MH. (2009) Plant extracts with anti-inflammatory properties - A new approach for characterization of their bioactive compounds and establishment of structure-antioxidant activity relationships. Bioorg Med Chem 17: 1876-1883.

17. Alvarez-Suarez J M, Tulipani S, Romandini S, Vidal A, Battino M (2009) Methodological aspects about determination of phenolic compounds and in vitro evaluation of antioxidant capacity in the honey: a review. Current Analytical Chemistry 5: 292-302.
18. Ahmed M, Djebli N, Aissat S, Khiati B , Ünal M et al (2012) Antiradical Activity and Total Phenolics of Algerian Honeys and Antibacterial Effect Against GramNegative Bacteria. Journal of Microbial \& Biochemical Technology 4: 152-156.

19. Dong R, Zheng Y, Xu B (2011) Phenolic Profiles and Antioxidant Capacities of Chinese Unifloral Honeys from Different Botanical and Geographical Sources. Food Bioprocess Technol.

20. Al-Mamarya M, Al-Meerib A, Al-Haborib M (2002) Antioxidant activities and total phenolics of different types of honey. Nutrition Research 22: 1041-1047.

21. Regina L P, Sant'Ana L D, Echevarriaa A, Castro R N (2012) Antioxidant Activity and Phenolic Composition of Brazilian Honeys and their Extracts. J. Braz. Chem. Soc 23: 618-627.

22. Khalil MI, Mahaneem M, Jamalullail SMS, Alam N, Sulaiman SA (2011) Evaluation of radical scavenging activity and colour intensity of nine Malaysian honeys of different origin. J ApiProduct ApiMedical Sci 3: 4-11.

23. Alvarez-Suarez J M, Tulipani S, Diaz D, Estevez Y, Romandini F G, et at (2010) Antioxidant and antimicrobial capacity of several monofloral Cuban honeys and their correlation with colour, polyphenol content and other chemical compounds. Food Chem Toxicol 48: 2490-2499.

24. Silici S, Sagdic O, Ekici L (2010) Total phenolic content, antiradical, antioxidant and antimicrobial activities of Rhododendron honeys. Food Chemistry 121 238-243.

25. Efem SE (1988) Clinical observations on the wound healing properties of honey. Br J Surg 75: 679-681.

26. Ahmed M, Djebli N, Aissat S, Zerrouki K, Bourabeh A (2013) In Vitro Synergistic Antibacterial Activity of Natural Honey Combined with Curcuma Starch and their Correlation with Diastase Number, Flavonoid and Polyphenol Content. Plant Pathology \& Microbiology 4:1.

27. Chirife J, Herszage L, Joseph A, Kohn ES (1983) In vitro study of bacteria growth inhibition in concentrated sugar solutions: microbiological basis for the use of sugar in treating infected wounds. Antimicrob Agents Chemother 23 766-773.

28. Ahmed M, Djebli N, Aissat S, Bacha S, Meslem A, et al. (2012) Synergistic Inhibition of Natural Honey and Potato Starch and their Correlation with Diastase Number and Sugar Content Against Klebsiella pneumoniae ATCC 27736. Natural Products Chemistry \& Research 1:1.

29. Escuredo O, Luís S, Valentão P, Seijoa M, Andrade P (2012) Assessing Rubus honey value: Pollen and phenolic compounds content and antibacterial capacity. Food Chemistry 130, 671-678.

30. Lee H, Churey JJ, Worobo RW (2008) Antimicrobial activity of bacterial isolates from different floral sources of honey. Int J Food Microbiol 126: 240-244.

31. Xiao J, Kai G, Ni X, Yang F, Chen X (2011) Interaction of natural polyphenols with $\hat{I} \pm$-amylase in vitro: molecular property-affinity relationship aspect. Mol Biosyst 7: 1883-1890. 